\title{
Corrosion behavior of hydroxyapatite coated AZ31 and AZ91 Mg alloys by electrostatic spray coating
}

https://doi.org/10.1515/ijmr-2021-8310

Received April 12, 2021; accepted September 30, 2021

\begin{abstract}
Magnesium and its alloys are excellent implant material candidates with their biodegradable structure and mechanical properties close to human bone. In order to provide the desired strength in implant applications, the corrosion resistance of the materials is expected to be high. In this study, to improve the corrosion resistance of AZ31 and AZ91 magnesium alloys, an electrostatic hydroxyapatite coating process was applied, and optimum conditions were determined. The samples were structurally characterized by scanning electron microscopy/energy dispersive $\mathrm{X}$-ray spectroscopy and stereo microscopy methods, and their corrosion behavior was determined by the weight loss method. As a result of the coating, the corrosion resistance of the samples increased up to $250 \%$.
\end{abstract}

Keywords: Biodegradable; Ceramic coating; Electrostatic spraying; Hydroxyapatite; Mg alloys.

\section{Introduction}

In the last two decades, research on the use of Mg alloys as biodegradable implant material has been increasing. The use of $\mathrm{Mg}$ is becoming increasingly important in dental applications, cardiovascular applications, and hard tissue replacements in the skeletal system. Unlike traditional bio alloys, $\mathrm{Mg}$ is biodegradable, its mechanical properties are

\footnotetext{
*Corresponding author: Serkan Baslayici, Metallurgical and Materials Eng. Dep., Istanbul Technical University, Istanbul, Turkey; and Construction Technology Dept., Istanbul Medipol University Vocational School, Kavacık Mah. Ekinciler Cd. No: 19, Beykoz/Istanbul, Turkey, E-mail: sbaslayici@medipol.edu.tr. https://orcid.org/00000002-7933-5887

Mehmet Bugdayci, Construction Technology Dep., Istanbul Medipol University, Istanbul, Turkey; and Department of Chemical Engineering, Yalova University, Yalova, Turkey,

E-mail: mehmet.bugdayci@yalova.edu.tr

Kagan Benzesik, Onuralp Yucel and Mahmut Ercan Acma, Metallurgical and Materials Eng. Dep., Istanbul Technical University, Istanbul, Turkey, E-mail: kaganbenzesik@gmail.com (K. Benzesik),

yucel@itu.edu.tr (0. Yucel), ercana@itu.edu.tr (M. Acma)
}

very close to human bone, and $\mathrm{Mg}$ ions have an accelerating effect on bone repair, which is the driving force behind the idea of producing Mg-based implants. However, for $\mathrm{Mg}$ to be used as an implant, the corrosion rate must be reduced. It is possible to achieve this with alloying and surface modification or both [1-10].

Two of the issues to be considered when designing biodegradable implants are corrosion rate and corrosion products. If the corrosion rate is too high, the implant will degrade before it can fulfill its function. On the other hand, if the corrosion rate is too low, it will not degrade in the body at the desired time. Corrosion products should not be toxic and should not exceed the daily amounts tolerated by the human. For $\mathrm{Fe}$, one of the potential biodegradable implant material candidates, the corrosion rate being less than expected is an important problem. For $\mathrm{Zn}$, the fact that excess $\mathrm{Zn}$ intake is harmful to the human body is one of the limiting factors. On the other hand, $\mathrm{Mg}$ attracts the attention of researchers with its positive results in both areas [11-19].

Stress shielding is a situation that causes the bone to become sluggish during the healing process when there is too much difference between the elasticity modulus of the bone and the bio alloy used in hard tissue changes, because the implant will be much more rigid than the bone. The fact that the elasticity modulus of $\mathrm{Mg}$ is close to the elasticity module of the bone is also an encouraging factor for its use in hard tissue replacements [20-27].

Hydroxyapatite is a CaP-based bioactive ceramic with a similar structure to apatite found in the human body. For a CaP compound to be named as hydroxyapatite, the molar ratio of $\mathrm{Ca} / \mathrm{P}$ must be at least 1.67. It has hexagonal crystal structure with $\mathrm{Ca}_{5}\left(\mathrm{PO}_{4}\right)_{3}(\mathrm{OH})$ formula. It is used both in soft tissue replacements and as the surface coating of metallic implants used in hard tissue replacements.

The main reasons for using hydroxyapatite in the surface modification of bio alloys are its biocompatibility, providing surface roughness for implants to adhere to tissue, and preventing bio alloys from being identified by the body as foreign matter [28-34].

There is a lot of research on the coating of traditional bio alloys 316L stainless steel and Ti alloys with hydroxyapatite and many methods are recommended. The 
main recommended methods are plasma spray coating, electrophoretic coating, sol-gel coating, dip coating, electrostatic spray coating, magnetron sputter coating and radio frequency coating. However, only a limited number of these methods are applicable for Mg alloys. Especially, the fact that the melting temperature of $\mathrm{Mg}$ is lower than the other two metals mentioned is a very limiting factor $[10,18,24,35]$.

Methods such as sol-gel coating and dip coating are performed in liquid medium, the process steps are difficult and consequently difficult to apply on $\mathrm{Mg}$ [11, 17, 18, 22, 25, 32].

Electrophoretic coating is the most common and widely used method. However, with its ease of application, plasma spray coating and electrostatic coating have recently come to the fore.

Electrostatic spray coating is seen as a method used for coating enamel-like ceramics, especially on steel surfaces $[2,4,12,30,32,36]$.

In this study, the corrosion rates of AZ31 and AZ91 Mg alloys coated with hydroxyapatite by electrostatic spray coating in simulated body fluid were determined.

\section{Experimental procedure}

The Mg alloys used in the experiments were provided by the Luoyang Magnesium Gurnee Metal Material Co., Ltd. According to the results of scanning electron microscopy/energy dispersive X-ray spectroscopy (SEMEDS) applied to the samples, the Mg fraction of AZ31 was determined as $96.54 \mathrm{Al}$ fraction 2.49 and $\mathrm{Zn}$ fraction 0.96. The Mg fraction of AZ91 was determined as 91.32, $\mathrm{Al}$ fraction 7.69 and $\mathrm{Zn}$ fraction 0.99 . So, EDS results proved these materials are AZ31 and AZ91. Mg alloys used as substrate material are $50 \times 10 \times 2 \mathrm{~mm}$ in size.

The purity of hydroxyapatite used as coating material was $99 \%$. The HA was supplied by Xi'an Realin Biotechnology Co.,Ltd. The impurities in the hydroxyapatite were sulphate $<0.048 \%$, chloride $<0.05 \%$ and heavy metals $<10$ ppm.

A flowchart of the experimental process is shown in Figure 1.

\subsection{Electrostatic spray coating and sintering}

In the electrostatic spray method, the powder material to be used for coating is negatively charged by applying high voltage, while the part to be coated is positively charged. Powder suspension passes through the tube in the center

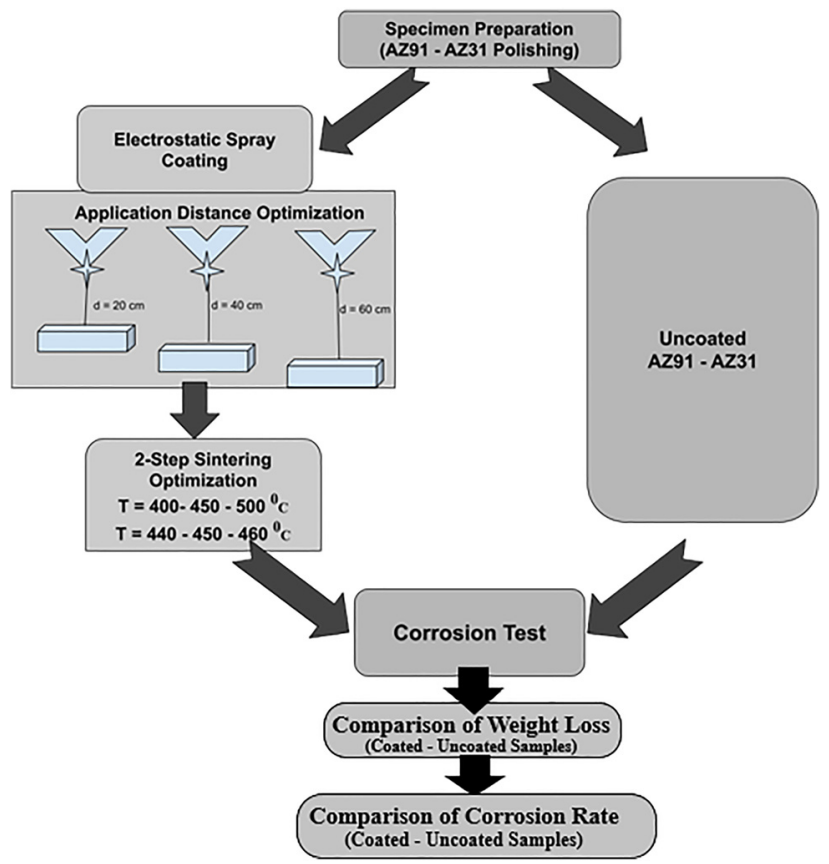

Figure 1: Flowchart of the experimental process.

of the spray gun used in the electrostatic coating method, and air passes through the surrounding part. Powder particles under the effect of electric field begin to accumulate on the part to be coated by being negatively charged. As the electrostatic attraction force decreases due to the first particles coated during the deposition, other particles will start to accumulate in lower amounts. This opposite attraction will keep the coating thickness under control and thus homogeneous thickness coatings will be made. The most important parameter in this method is the formation of an electrostatic force greater than the gravitational force between the base material and the powder deposited on it. Thus, the powder will remain on the substrate material until the sintering process [37].

Devilbiss Pri-Pro spray gun was used in the electrostatic coating process. Hydroxyapatite powder was poured into the reservoir of the spray gun, and then sprayed on the AZ31 and AZ91 substrates with an air pressure of 3 bar. In this method, one of the most important parameters to make a successful coating, the coating thickness, must be optimized. The coating thickness is directly related to the rate of the powder accumulation on the substrate. The distance between the electrostatic spray gun and the substrate material during the application also affects this accumulation rate. Therefore, in order to obtain the optimum coating thickness, the coating process has been tried at $20 \mathrm{~cm}, 40 \mathrm{~cm}$ and $60 \mathrm{~cm}$ distances to determine the optimum coating distance. It was observed that the $8 \mathrm{~h}$ period was insufficient for a 
successful adhesion between hydroxyapatite and substrate material.

Then, the substrate materials coated with hydroxyapatite were sintered for $8 \mathrm{~h}$ at 400,450 and $500{ }^{\circ} \mathrm{C}$, respectively. A muffle furnace was used for the sintering process. Subsequently, sintering times of $24 \mathrm{~h}$ and $48 \mathrm{~h}$ were tried. Finally, a sintering time of $24 \mathrm{~h}$ was tested at 440,450 and $460{ }^{\circ} \mathrm{C}$.

After these tests, sintering experiments were carried out at $450^{\circ} \mathrm{C}$ for $24 \mathrm{~h}$. In the case of sintering at higher temperatures, the maximum temperature that can be applied has been applied, since burning occurs in the litter material. No protective atmosphere was used, because Hydroxyapatite is a structure containing oxide.

\subsection{Corrosion testing}

After electrostatic coating, corrosion studies were carried out by the weight loss method according to the ASTM G3172 standard. Here, the corrosion rate was determined by using Equation (1) specified in the standard. Where $K(8.76$ $.10^{4} \mathrm{~mm}$ per year $\left.\left(\mathrm{mm} \mathrm{y}^{-1}\right)\right)$ is a constant, $A$ area in $\mathrm{cm}^{2}, T$ time of exposure in hour, $W(\mathrm{~g})$ weight loss and $D\left(\mathrm{~g} \mathrm{~cm}^{-3}\right)$ density.

$$
\text { Corrosion Rate }=\frac{K \cdot W}{A \cdot T \cdot D}
$$

\subsection{Characterization of samples}

In this study SEM and stereo microscopy techniques were used for characterization. A ZEISS GeminiSEM 500 was used for microstructural analyses both for uncoated and coated alloys. Also, energy dispersive X-ray spectroscopy (EDS) was used for chemical analyses of alloys. A Bestscope SMT-3020T Stereo Microscope was used to measure coating thickness.

\section{Results and discussion}

In this study, electrostatic spray coating was applied, and corrosion rates of coated samples were determined by experimental studies. The optimum value was determined for the application distance, which is one of the important parameters in this coating method. After that, the optimum sintering temperature was determined. Due to the difference between the optimum service temperature of magnesium and the optimum sintering temperature of hydroxyapatite, sintering was performed at the maximum temperature at which the alloy can be used. The optimum sintering temperature was determined as $450^{\circ} \mathrm{C}$. SEM and stereo microscopy results were obtained for the sintered samples for varying application distance in electrostatic spray coating. a

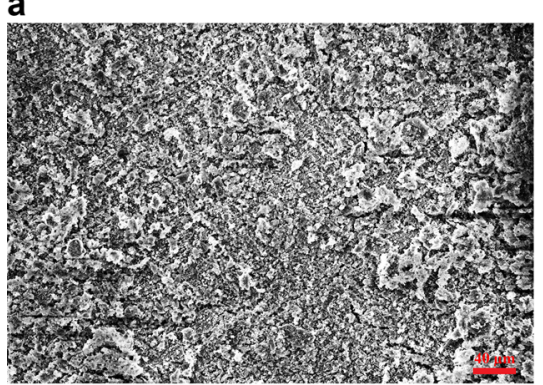

d

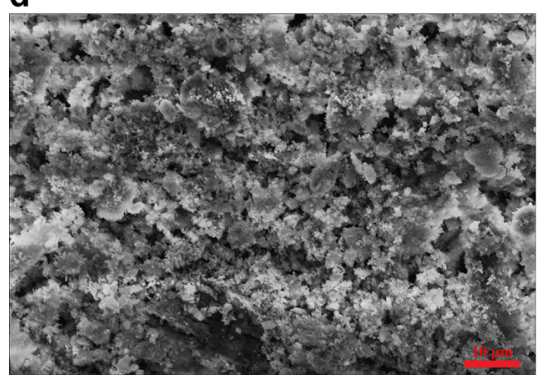

b

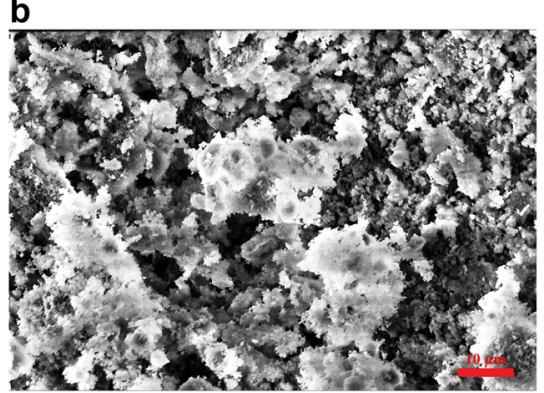

e

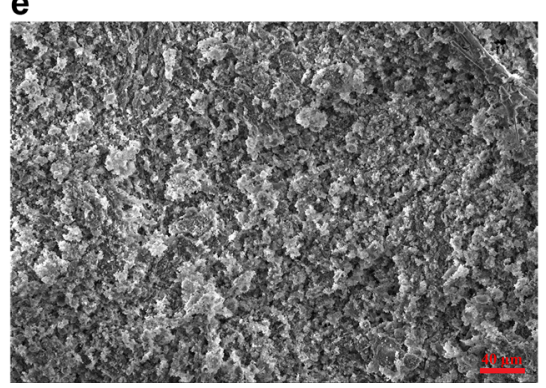

C

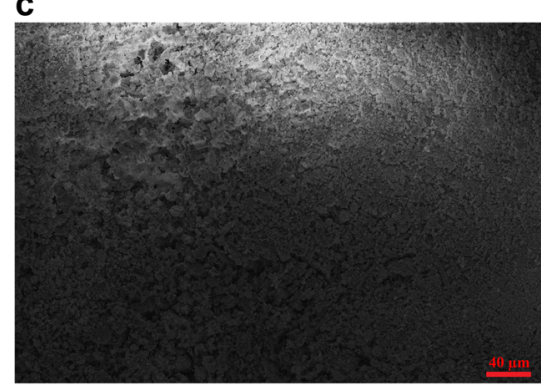

f

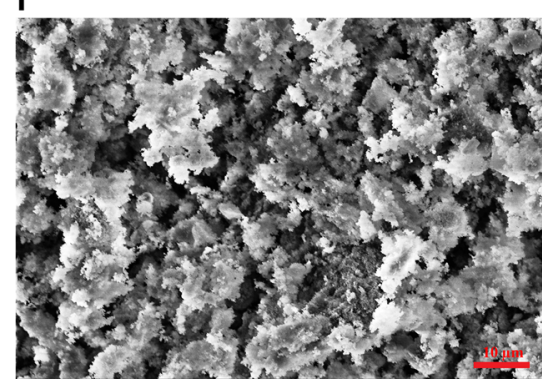

Figure 2: SEM images of AZ31 sample coated with hydroxyapatite by the electrostatic coating method (a) from $20 \mathrm{~cm}$ distance $500 \times$, (b) from $20 \mathrm{~cm}$ distance $2500 \times$, (c) from $40 \mathrm{~cm}$ distance $500 \times$, (d) from $40 \mathrm{~cm}$ distance $2500 \times$, (e) from $60 \mathrm{~cm}$ distance $500 \times$, (f) from $60 \mathrm{~cm}$ distance $2500 \times$. 
Electrostatic coating was applied to AZ31 from 20, 40 and $60 \mathrm{~cm}$ distances, and the findings are shown in Figure 2 sections ( $\mathrm{a}$ and $\mathrm{b}, \mathrm{c}$ and $\mathrm{d}$ and $\mathrm{e}$ and $\mathrm{f}$ ), respectively.

The same procedure applied to AZ31 in Figure 2 was applied to AZ91 in Figure 3 and the findings are shown in the images.

As a result of electrostatic coating applied to AZ91 magnesium alloy from different distances, the best result was obtained with a value of $20 \mathrm{~cm}$. The thickness of the coatings made from this distance was measured. Stereo microscopy images are given in Figure 4a, after coating of the AZ91 Mg alloy with hydroxyapatite by the electrostatic spray method. It is seen here that the coating is continuous and homogeneous. The coating thickness for AZ91 is given in Figure 4b. Here, the coating thickness is over $120 \mu \mathrm{m}$. Stereo microscopy images are given after the hydroxyapatite coating of AZ31 Mg alloy by electrostatic spray method in Figure 4c. It is seen here that the coating is continuous and homogeneous. Measurement of coating thickness for AZ31 is given in Figure 4d. Here, the coating thickness is about $115 \mu \mathrm{m}$.

At this stage, the process of coating the alloys with the electrostatic spray coating method, which is the first step of the experimental studies, has been completed. The a

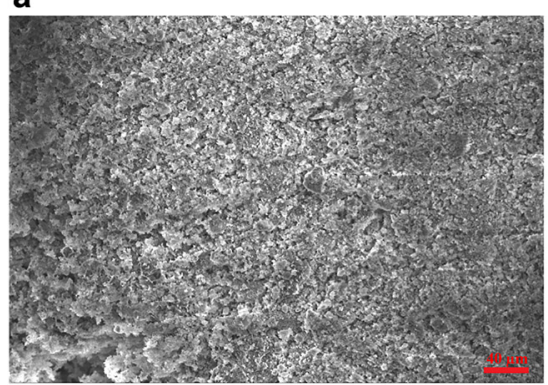

d

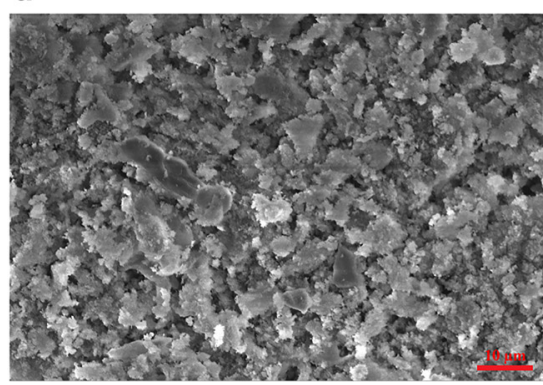

b

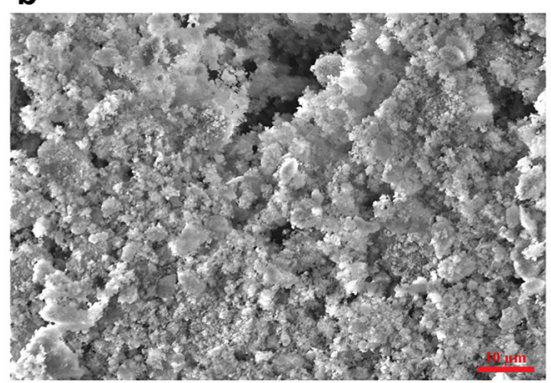

e

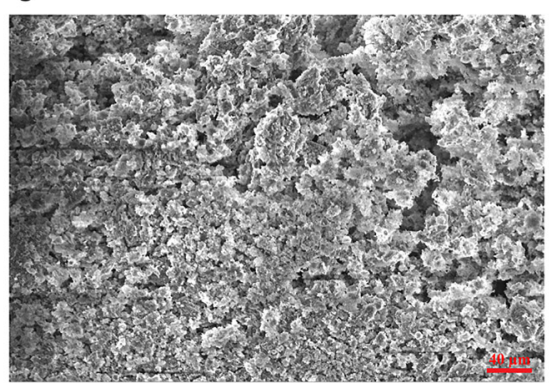

C

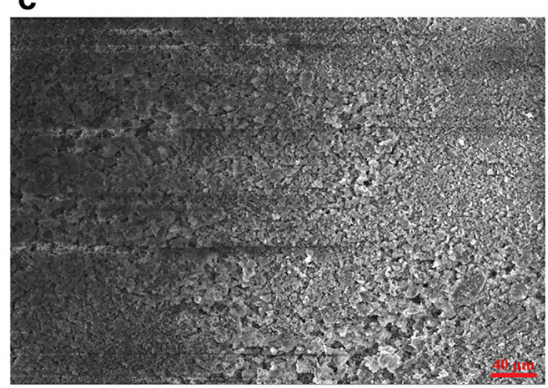

f

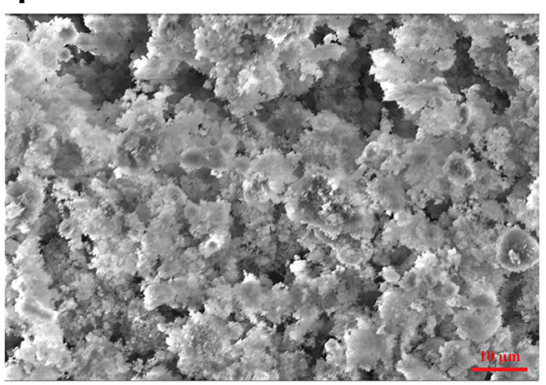

Figure 3: SEM images of AZ91 sample coated with hydroxyapatite by electrostatic coating method (a) from $20 \mathrm{~cm}$ distance $500 \times$, (b) from 20 $\mathrm{cm}$ distance $2500 \times$, (c) from $40 \mathrm{~cm}$ distance $500 \times$, (d) from $40 \mathrm{~cm}$ distance $2500 \times$, (e) from $60 \mathrm{~cm}$ distance $500 \times$ (f) from $60 \mathrm{~cm}$ distance $2500 \times$.

a

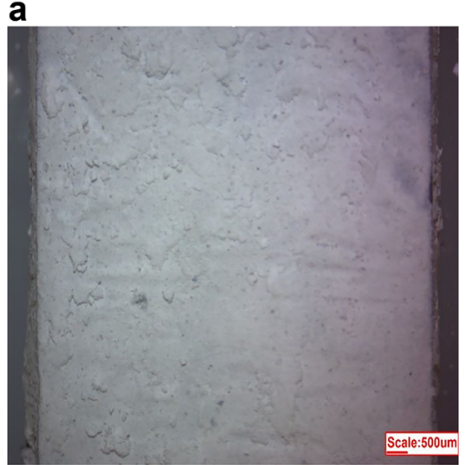

b

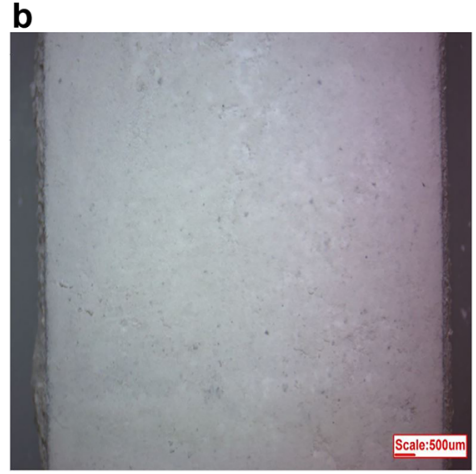

C

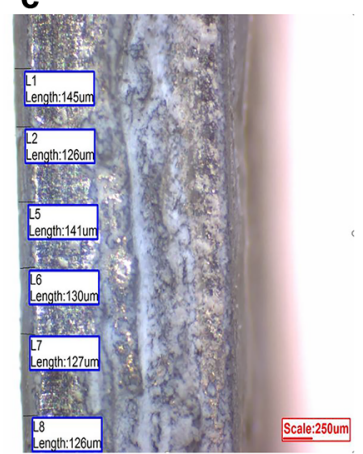

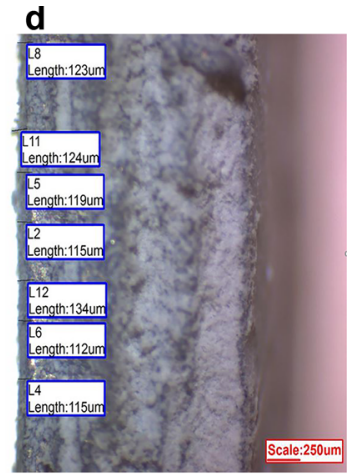

Figure 4: Stereo microscopy images of hydroxyapatite coating on (a) AZ91 Mg alloy, (b) AZ31 Mg alloy, and coating thickness of (c) AZ91 Mg alloy, (d) AZ31 Mg alloy by electrostatic spray method. 
Table 1: Weight losses of uncoated samples.

\begin{tabular}{llc}
\hline Time (h) & Alloy & Weight loss (mg) \\
\hline 1 & AZ31 & 0.8 \\
1 & AZ91 & 0.8 \\
24 & AZ31 & 7.1 \\
24 & AZ91 & 7.1 \\
168 & AZ31 & 47.8 \\
168 & AZ91 & 47 \\
504 & AZ31 & 127 \\
504 & AZ91 & 123.1 \\
\hline
\end{tabular}

sintering temperature and application distance have been optimized by determining the surface morphology and coating thickness of the coatings. According to the results, in the coating of magnesium alloys with hydroxyapatite by the electrostatic coating method, it has been determined that the most suitable application distance is $20 \mathrm{~cm}$ and the most suitable sintering conditions are $24 \mathrm{~h}$ and $450{ }^{\circ} \mathrm{C}$.

In the second stage, the corrosion tests were carried out. For corrosion testing, coated samples were subjected to weight loss testing in SBF and the same process was applied for the uncoated samples. Corrosion rates were calculated according to weight loss and the results were compared.
Corrosion tests were carried out according to ASTM G31-72 Standard. The weight loss of uncoated alloys is shown in Table 1.

The comparison of weight loss of AZ31 and AZ91 alloys is shown in Figure 5a. It can be seen from the figure that the weight loss of the AZ91 alloy is slightly less. The reason for this can be interpreted as the amount of alloying element it contains has increased the corrosion resistance.

Corrosion rates of uncoated alloys are shown in Table 2. In Figure 5b, corrosion rates of AZ31 and AZ91 alloys are compared.

At the end of $504 \mathrm{~h}, 127 \mathrm{mg}$ weight loss was observed in AZ31 alloy, while $123.1 \mathrm{mg}$ were observed for AZ91 under the same conditions. While the corrosion behavior of the materials showed similar changes, it was seen that AZ91 provided slightly better protection than AZ31. Corrosion rates for both alloys were quite high in the first hours and became more stable after $24 \mathrm{~h}\left(1.21 \mathrm{~mm} \mathrm{y}^{-1}\right.$ for AZ31 and $1.14 \mathrm{~mm} \mathrm{y}^{-1}$ after $504 \mathrm{~h}$ for AZ91).

Weight losses of samples coated by electrostatic spraying are given in Table 3. The effect of electrostatic spray coating on weight loss according to Tables 1 and 3 is shown in Figure $6 \mathrm{a}$ for AZ31 and Figure $6 \mathrm{~b}$ for AZ91. When Figure 6a is examined, weight loss decreased from $127 \mathrm{mg}$ to $49.6 \mathrm{mg}$ after $504 \mathrm{~h}$ by coating. According to Figure $6 \mathrm{~b}$, a
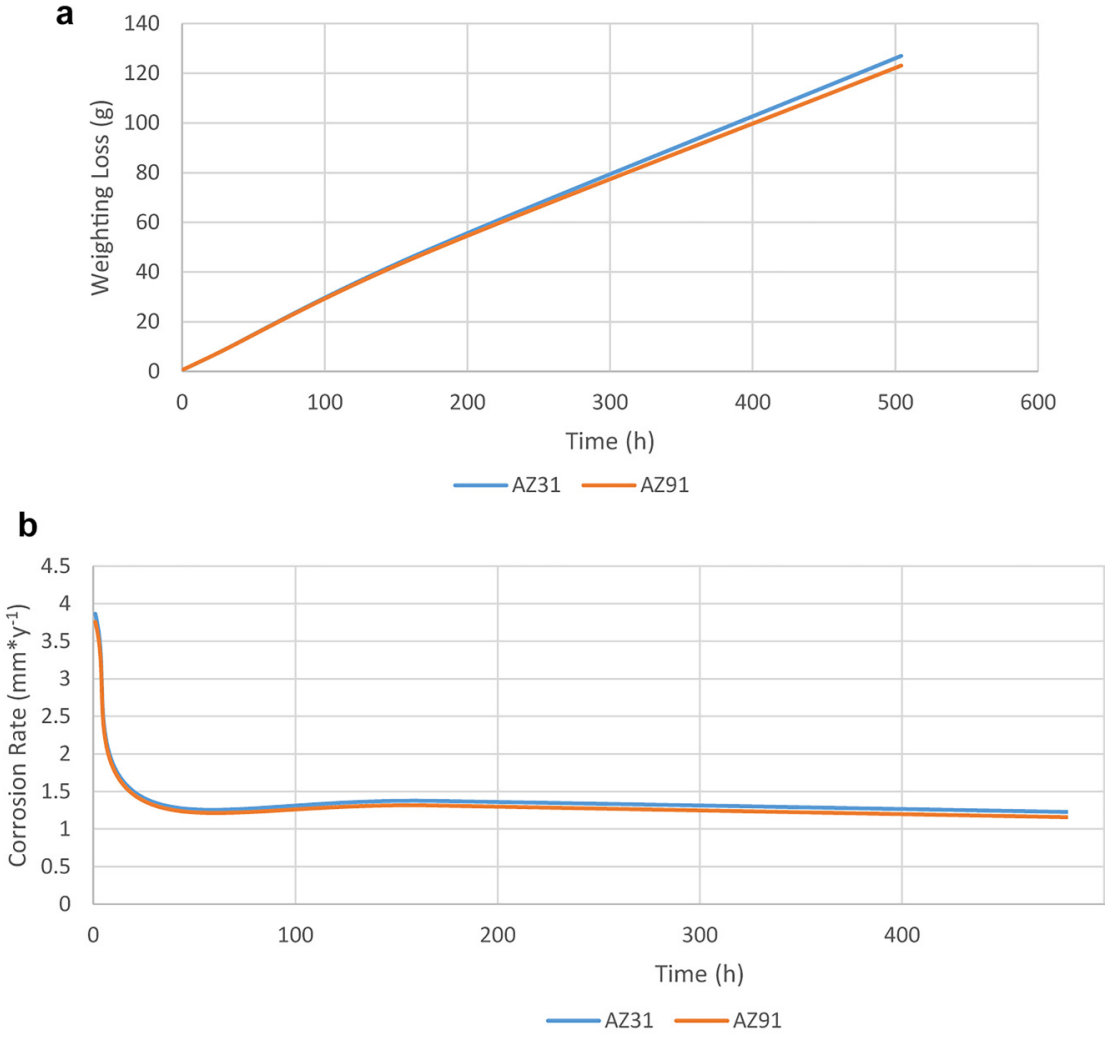

Figure 5: Comparison of (a) weight losses, and (b) corrosion rates of uncoated AZ31 and AZ91 alloys. 
Table 2: Corrosion rates of uncoated samples.

\begin{tabular}{llr}
\hline Time $(\mathbf{h})$ & Alloy & Corrosion rate $\left(\mathrm{mm} \mathrm{y}^{-\mathbf{1}}\right)$ \\
\hline 1 & AZ31 & 3.8640 \\
1 & AZ91 & 3.7567 \\
24 & AZ31 & 1.4288 \\
24 & AZ91 & 1.3892 \\
168 & AZ31 & 1.3742 \\
168 & AZ91 & 1.3137 \\
504 & AZ31 & 1.2170 \\
504 & AZ91 & 1.1469 \\
\hline
\end{tabular}

Table 3: Weight losses of coated samples.

\begin{tabular}{llr}
\hline Time (h) & Alloy & Weight loss (mg) \\
\hline 1 & AZ31 & 0.2 \\
1 & AZ91 & 0.2 \\
24 & AZ31 & 3.7 \\
24 & AZ91 & 3.5 \\
168 & AZ31 & 17.8 \\
168 & AZ91 & 17.2 \\
504 & AZ31 & 49.6 \\
504 & AZ91 & 48.7 \\
\hline
\end{tabular}

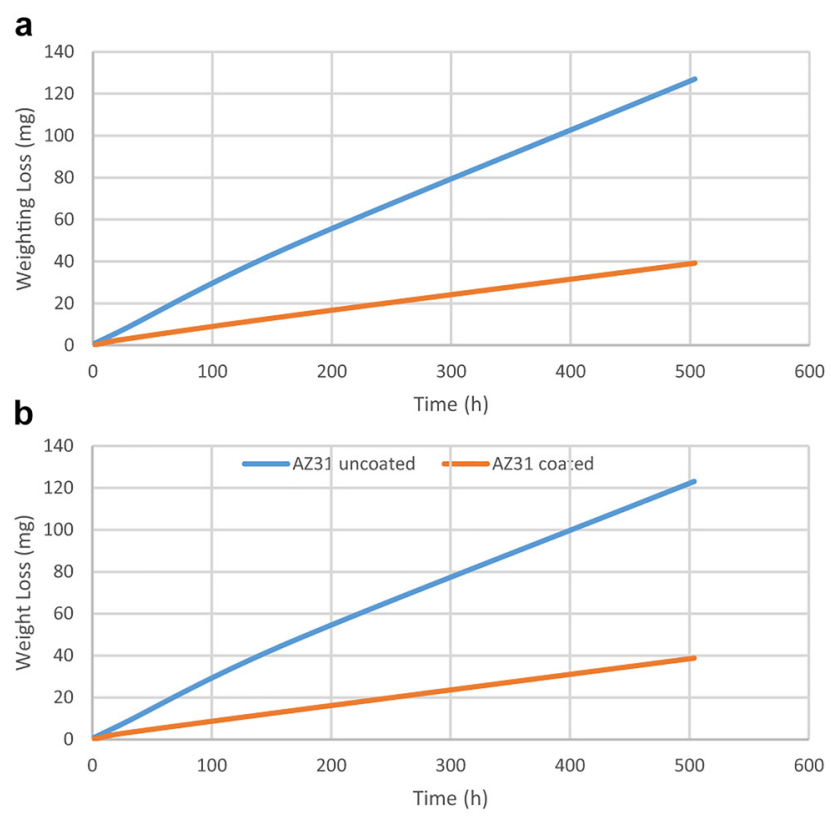

AZ91 uncoated $\quad$ AZ91 coated

Figure 6: Effect of coating on weight losses of (a) AZ31 alloy, (b) AZ91 alloy.

the weight loss decreased from $123.1 \mathrm{mg}$ to $48.7 \mathrm{mg}$ after $504 \mathrm{~h}$ by coating.

Corrosion rates of samples coated by electrostatic spraying are given in Table 4. From Tables 2 and 4, the
Table 4: Corrosion rate of coated samples.

\begin{tabular}{llr}
\hline Time (h) & Alloy & Corrosion rate $\left(\mathrm{mm} \mathrm{y}^{\mathbf{- 1}}\right)$ \\
\hline 1 & AZ31 & 0.966 \\
1 & AZ91 & 0.939 \\
24 & AZ31 & 0.745 \\
24 & AZ91 & 0.685 \\
168 & AZ31 & 0.512 \\
168 & AZ91 & 0.481 \\
504 & AZ31 & 0.475 \\
504 & AZ91 & 0.454 \\
\hline
\end{tabular}
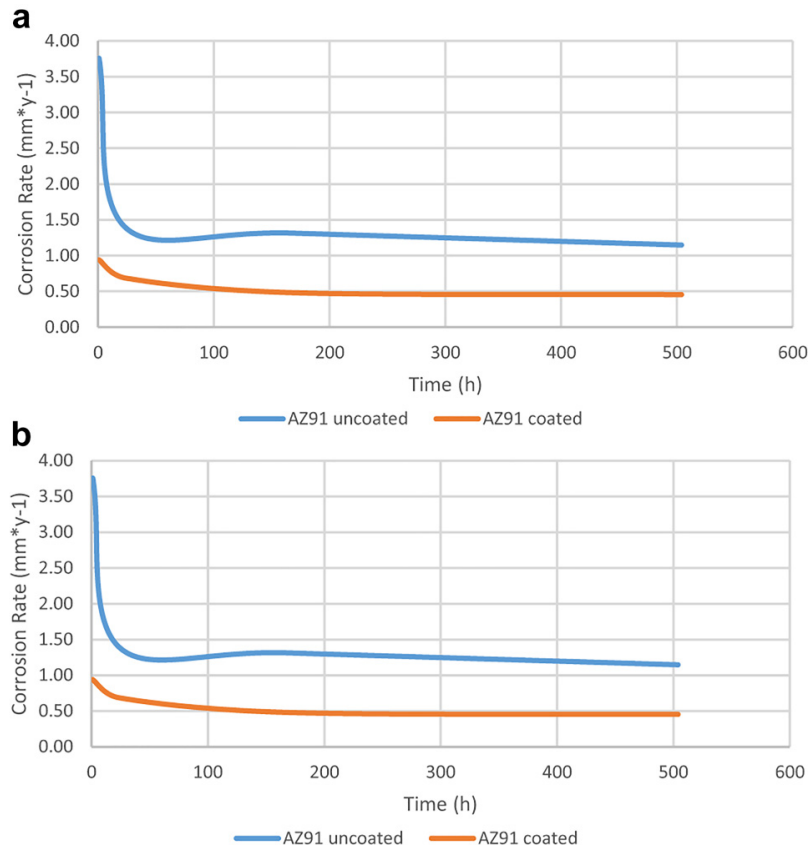

Figure 7: Effect of coating on corrosion rates of (a) AZ31 alloy, (b) AZ91 alloy.

effect of electrostatic spray coating on corrosion rate is shown in Figure 7a for AZ31 and in Figure 7b for AZ91.

In Figure $7 \mathrm{a}$, the corrosion rate obtained at $3.86 \mathrm{~mm}$ $\mathrm{y}^{-1}$ after $1 \mathrm{~h}$ was determined as $0.966 \mathrm{~mm} \mathrm{y}^{-1}$ in the coated AZ31 sample. In Figure 7b where the corrosion rate of AZ91 was examined, the corrosion rate of $3.75 \mathrm{~mm} \mathrm{y}^{-1}$ in the uncoated sample decreased to $0.939 \mathrm{~mm} \mathrm{y}^{-1}$ after $1 \mathrm{~h}$ in the coated sample.

\section{Conclusions}

In the first stage of our study, which consisted of two stages, it was found that magnesium alloys can be successfully coated with hydroxyapatite by the electrostatic 
coating method. For this method, application from $20 \mathrm{~cm}$ distance gives the best result. Sintering for $24 \mathrm{~h}$ at $450{ }^{\circ} \mathrm{C}$ is the most suitable option during the sintering stage.

When coating thicknesses are examined, it is possible to obtain coatings with a thickness of $115 \mu \mathrm{m}$ with this method. It has been observed that the coatings are continuous and homogeneous. Hydroxyapatite coatings are usually seen between 50 and $200 \mu \mathrm{m}$ [38]. It is predicted that a thickness of $100 \mu \mathrm{m}$ is sufficient.

In the second stage of our experimental study, first, corrosion rates of AZ31 and AZ91 magnesium alloys without any coating were compared. Accordingly, it was found that AZ91 has a slightly better corrosion resistance.

Although it will not give accurate results due to the fact that the SBF used is not the same, it was found that the weight loss of AZ31 and AZ91 Magnesium alloys is approximately $45 \%$ less at the end of $24 \mathrm{~h}$ compared to the weight loss experiments of pure magnesium in the literature [3].

It was found that after coating the AZ91 with electrostatic coating of hydroxyapatite, the corrosion rate reduced from $1.1469 \mathrm{~mm} \mathrm{y}^{-1}$ to $0.454 \mathrm{~mm} \mathrm{y}^{-1}$ at the end of $504 \mathrm{~h}$. After plasma spray coating, it was seen that it reduced the corrosion rate to $0.36158 \mathrm{~mm} \mathrm{y}^{-1}$ after $504 \mathrm{~h}$ [39].

When the effect of coating magnesium alloys with hydroxyapatite on corrosion behavior was investigated; it was found that the hydroxyapatite coating significantly reduced the corrosion rate. After $504 \mathrm{~h}$, it was found that the hydroxyapatite coating reduced the corrosion rate by 2.56 times for AZ31 alloy and 2.53 times for AZ91 alloy. Generally, it has been determined that the corrosion resistance of magnesium alloys was increased by $250 \%$ as a result of hydroxyapatite coating with the electrostatic spray method.

Author contribution: All the authors have accepted responsibility for the entire content of this submitted manuscript and approved submission.

Research funding: None declared.

Conflict of interest statement: The authors declare no conflicts of interest regarding this article.

\section{References}

1. Kamrani S., Fleck C. Biometals 2019, 32, 185. https://doi.org/ 10.1007/s10534-019-00170-y.

2. Wen C., Guan S., Peng L., Ren C., Wang X., Hu Z. Appl. Surf. Sci. 2009, 255, 6433. https://doi.org/10.1016/j.apsusc.2008.09 .078 .

3. Zhang Y., Zhang G., Wei M. J. Biomed. Mater. Res. B Appl. Biomater. 2009, 89, 408. https://doi.org/10.1002/jbm.b .31228 .
4. Xu L., Pan F., Yu G., Yang L., Zhang E., Yang K. Biomaterials 2009, 30, 1512. https://doi.org/10.1016/j.biomaterials.2008 .12 .001$.

5. Li Z., Gu X., Lou S., Zheng Y. Biomaterials 2008, 29, 1329. https://doi.org/10.1016/j.biomaterials.2007.12.021.

6. Khalajabadi S. Z., Abdul Kadir M. R., Izman S., Ebrahimi-Kahrizsangi R. Mater. Des. 2015, 88, 1223. https:// doi.org/10.1016/j.matdes.2015.09.065.

7. Jo J. H., Kang B. G., Shin K. S., Kim H. E., Hahn B. D., Park D. S., Koh Y. H. J. Mater. Sci. Mater. Med. 2011, 22, 2437-2447. https://doi.org/10.1007/s10856-011-4431-3.

8. Gu X., Zheng Y., Cheng Y., Zhong S., Xi T. Biomaterials 2009, 30, 484. https://doi.org/10.1016/j.biomaterials.2008.10.021.

9. Witte F., Fischer J., Nellesen J., Crostark H., Kaese V., Pisch A., Beckmann F., Windhagen H. Biomaterials 2006, 27, 113. https://doi.org/10.1016/j.biomaterials.2005.07.037.

10. Staiger M. P., Pietak A. M., Huadmai J., Dias G. Biomaterials 2006, 27, 1728. https://doi.org/10.1016/j.biomaterials.2005 .10 .003 .

11. Lakstein D., Kopelovitch W., Barkay Z., Bahaa M., Hendel D., Eliaz N. Acta Biomater. 2009, 5, 2258. https://doi.org/10 .1016/j.actbio.2009.01.033.

12. Bigi A., Fini M., Bracci B., Boanini E., Torricelli P., Giavaresi G., Aldini N. N., Facchini A., Sbaiz F., Giardino R. Biomaterials 2008, 29, 1730. https://doi.org/10.1016/j.biomaterials.2007 .12 .011 .

13. Hahn B. D., Cho Y. L., Park D. S., Choi J. J., Ryu J., Kim J. W., Ahn C. W., Park C., Kim H. E., Kim S. G. J. Biomater. Appl. 2013, 27, 587. https://doi.org/10.1177/0885328211415723.

14. Chen X., Zhang M., Pu X., Yin G., Liao X., Huang Z., Yao Y. Surf. Coating. Technol. 2014, 249, 97. https://doi.org/10.1016/j .surfcoat.2014.03.056.

15. Wang Y., Wei M., Gao J. Mater. Sci. Eng. C 2009, 29, 1311. https://doi.org/10.1016/j.msec.2008.09.051.

16. Hagihara K., Fujii K., Matsugaki A., Nakano T. Mater. Sci. Eng. C 2013, 33, 4101. https://doi.org/10.1016/j.msec.2013.05 .055 .

17. Kayali Y., Aslan O., Karabaş M., Talaş Ş. Protect. Met. Phys. Chem. Surface 2016, 52, 1079. https://doi.org/10.1134/ S2070205116060113.

18. Lewis G. J. Adv. Nanomater. 2017, 2, 65. https://doi.org/10 .22606/jan.2017.21007.

19. Zakiyuddin A., Lee K. J. Alloys Compd. 2015, 629, 274. https:// doi.org/10.1016/j.jallcom.2014.12.181.

20. Kannan M. B., Raman R. K. S. Biomaterials 2008, 29, 2306. https://doi.org/10.1016/j.biomaterials.2008.02.003.

21. Chen Y., Xu Z., Smith C., Sankar J. Acta Biomater. 2014, 10, 4561. https://doi.org/10.1016/j.actbio.2014.07.005.

22. Chiu K. Y., Wong M. H., Cheng F. T., Man H. C. Surf. Coating. Technol. 2007, 202, 590. https://doi.org/10.1016/j.surfcoat .2007.06.035.

23. Song G., Song S. Adv. Eng. Mater. 2007, 9, 298. https://doi .org/10.1002/adem.200600252.

24. Chen X. B., Birbilis N., Abbott T. B. Corrosion Sci. 2011, 53, 2263. https://doi.org/10.1016/j.corsci.2011.03.008.

25. Kannan M. B. Hydroxyapatite (HAp) for Biomedical Applications; Mucalo M., Ed.; Elsevier: UK, Vol. 13, 2015; p. 289. 
26. Witte F., Feyerabend F., Maier P., Fischer J., Störmer M., Blawert C., Dietzel W., Hort N. Biomaterials 2007, 28, 2163. https://doi.org/10.1016/j.biomaterials.2006.12.027.

27. Zheng Y. F., Gu X. N., Witte F. Mater. Sci. Eng. R Rep. 2014, 77, 1. https://doi.org/10.1016/j.mser.2014.01.001.

28. Hayakawa S. Hydroxyapatite (HAp) for Biomedical Applications; Mucalo M., Ed.; Elsevier: UK, Vol. 4, 2015; p. 85.

29. Guan K., Zhang L., Zhu F., Li H., Sheng H., Guo Y. J. Alloys Compd. 2020, 821, 153543. https://doi.org/10.1016/j.jallcom .2019 .153543 .

30. Bose S., Tarafder S., Bandyopadhyay A. Hydroxyapatite (HAp) for Biomedical Applications; Mucalo M., Ed.; Elsevier: UK, Vol. 7, 2015; p. 143.

31. Lin K., Chang J. Hydroxyapatite (HAp) for Biomedical Applications; Mucalo M., Ed.; Elsevier: UK, Vol. 1, 2015; p. 3.

32. Onder S., Calikoglu-Koyuncu A. C., Kazmanli K., Urgen M., Torun Kose G., Kok F. N. Nat. Biotechnol. 2015, 32, 747. https://doi.org/10.1016/j.nbt.2014.11.006.
33. Ali M., Hussein M. A., Al-Aqeeli N. J. Alloys Compd. 2019, 792, 1162. https://doi.org/10.1016/j.jallcom.2019.04.080.

34. Dorozhkin S. V. Acta Biomater. 2014, 10, 2919. https://doi .org/10.1016/j.actbio.2014.02.026.

35. Schinhammer M., Hänzi A. C., Löffler J. F., Uggowitzer P. J. Acta Biomater. 2010, 6, 1705. https://doi.org/10.1016/j.actbio .2009.07.039.

36. Tahmasebifar A., Kayhan S. M., Evis Z., Tezcaner A., Çinici H., Koç M. J. Alloys Compd. 2016, 687, 906. https://doi.org/10 .1016/j.jallcom.2016.05.256.

37. Arcelormittal. User Manual: Steel for Enamelling and Enamelled Steel; 2008; p 1.

38. Sun L., Berndt C. C., Gross K. A., Kucuk A. J. Biomed. Mater. Res. 2001, 58, 570. https://doi.org/10.1002/ jbm.1056.

39. Baslayici S., Bugdayci M., Acma M. E. J. Ceram. Process. Res. 2021, 22, 98. https://doi.org/10.36410/jcpr.2021.22.1 .98 . 